\title{
NATIONAL WASTE TERMINAL STORAGE PROGRAM \\ PLANNING AND CONTROL SYSTEM MANUAL
}

September 1976

This report was prepared by Control Data Corporation under Purchase Order 86Y-16513V with Union Carbide Corporation, Nuclear Division. The subcontract was administered by the Office of Waste Isolation.

OFFICE OF WASTE ISOLATION

OAK RIDGE. TENNESSEE

prepared for the U.S. ENERGY RESEARCH AND DEVELOPMENT ADMINISTRATION under U.S. GOVERNMENT Contract W-7405 eng 26 


\section{DISCLAIMER}

This report was prepared as an account of work sponsored by an agency of the United States Government. Neither the United States Government nor any agency Thereof, nor any of their employees, makes any warranty, express or implied, or assumes any legal liability or responsibility for the accuracy, completeness, or usefulness of any information, apparatus, product, or process disclosed, or represents that its use would not infringe privately owned rights. Reference herein to any specific commercial product, process, or service by trade name, trademark, manufacturer, or otherwise does not necessarily constitute or imply its endorsement, recommendation, or favoring by the United States Government or any agency thereof. The views and opinions of authors expressed herein do not necessarily state or reflect those of the United States Government or any agency thereof. 


\section{DISCLAIMER}

Portions of this document may be illegible in electronic image products. Images are produced from the best available original document. 
This report was prepared as an account of work sponsored by the United States Government. Neither the United States nor the Energy Research and Development Administration, nor any of their employees, nor any of their contractors, subcontractors, or their employees, makes any warranty, express or implied, or assumes any legal liability or responsibility for the accuracy, completeness or usefulness of any information, apparatus, product or process disclosed, or represents that its use would not infringe privately owned rights. 


\title{
NATIONAL WASTE TERMINAL STORAGE PROGRAM
}

\section{PLANNING \\ AND}

\section{CONTROL SYSTEM MANUAL}

\author{
PREPARED BY \\ THE OFFICE OF WASTE ISOLATION \\ UNION CARBIDE CORPORATION-NUCLEAR DIVISION
}

SEPTEMBER 1976

HAn 
1-1 Background . . . . . . . . . . . . . . . . . . 1-1

1-2 NWTS Planning and Control System Objective. . . . . . . . . . 1-1

1-3 Scope . . . . . . . . . . . . . . . . . . . . 1-2

II NWTS PROGRAM . . . . . . . . . .......... 2-1

2-1 NWTS Program Objectives . . . . . . . . . . . . . . 2-1
A. ERDA.
$2-1$
B. OWI. $2-1$

2-2 Organization/Responsibilities . . . . . . . . . . . . . 2-2

A. Overview . . . . . . . . . . . . . . . 2-2

B. OWI Organization/Responsibilities. . . . . . . . . . . . 2-2

C. ERDA/ORO ..................... . 2-5

D. ERDA/DNFCP. . . . . . . . ......... . 2-5

2-3 Technical Approach . . . . . . . . . . . . . . . . 2-5

A. Overview ..................... 2-5

B. Sequence for Terminal Development . . . . . . . . . . 2-6

C. Master Schedules . . . . . . . . . . . . . . 2-8

II SYSTEM DEFINITION . . . . . . . . . . . . . . . . . . . 3-1

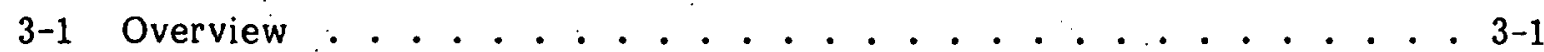

3-2 Work Breakdown Structure Concept . . . . . . . . . . . . . 3-1

3-3 NWTS Work Breakdown Structure . . . . . . . . . . . . 3-2

A. Project Sum mary Work Breakdown Structures (PSWBS) . . . . . . . 3-2

B. Contract Work Breakdown Structures (CWBS) . . . . . . . . . . 3-2

C. Project Work Breakdown Structures . . . . . . . . . . . 3-4

D. NWTS WBS Identification Numbering . . . . . . . . . . 3-4

3-4 Planning . . . . . . . . . . . . . . . . . . 3-6

A. Rolling Wave Concept . . . . . . . . . . . . . . . 3-6.

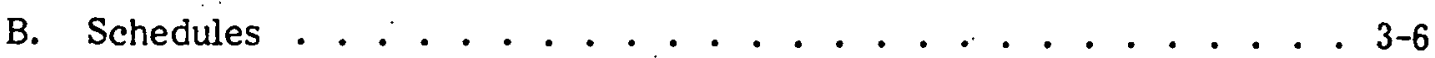

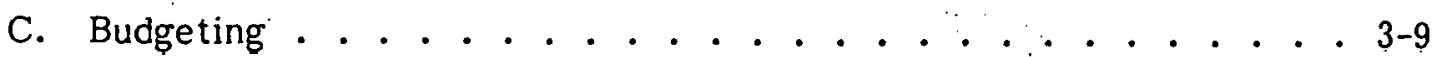


Table of Contents (Continued)

Section

3-5 Performance Control .................... . . . . . .

A. Introduction . . . . . . . . . . . . . . . 3-9

B. Earned Value Concept . . . . . . . . . . . . . . 3-9

C. Cost and Schedule Variances . . . . . . . . . . . . 3-10

D. Interpretation of Earned Value Relationships . . . . . . . . . 3-11

E. Technical Achievement . . . . . . . . . . . . 3-11

3-6 Status Reporting .. . . . . . . . . . . . . . . . 3-12

A. Media . . . . . . . . . . . . . . . . 3-12

B. Reporting Hierarchy. . . . . . . . . . . . . . . 3-13

3-7 Problem Identification. . . . . . . . . . . . . . . . . 3-13

3-8 Contractor Control . . . . . . . . . . . . . . . 3-13

A. Control Method Criteria . . . . . . . . . . . . 3-13

B. Control Method Number One . . . . . . . . . . . 3-14

C. Control Method Number Two . . . . . . . . . . . 3-14

3-9 Change Control...................... 3-14

IV SYSTEM IMPLEMENTATION . . . . . . . . . . . . . . . 4-1

4-1 Implementation Phases . . . . . . . . . . . . . . . 4-1

A. Phase I, Manual Operation . . . . . . . . . . . . . 4-1

B. Phase II, Automation . . . . . . . . . . . . . . . 4-1

C. Phase III, Expansion . . . . . . . . . . . . . . 4-1

4-2 OWI Work Breakdown Structure Form . . . . . . . . . . . . . 4-2

4-3 OWI Status Record Form . . . . . . . . . . . . . . . 4-5

A. Opening the Records ... . . . . . . . . . . . 4-5

B. Updating the Records .. . . . . . . . . . . . . 4-8

4-4 Status Reporting . . . . . . . . . . . . . . . . . . 4-10

A. Graphic Presentations . . . . . . . . . . . . . . 4-10

B. Narrative Reports. . . . . . . . . . . . . . . 4-11

C. NWTS Program/Projecl Reviews . . . . . . . . . . . . . 1-14

D. Reporting Hierarchy. . . . . . . . . . . . . . 4-15 
Table of Contents (Continued)

Section

Page

4-5 Contractor Control ..................... . 4-17
A. Control Method Selection . . . . . . . . . . . . 4-17
B. Control Method Number One Methodology . . . . . . . . . 4-17
C. Control Method Number Two Methodology . . . . . . . . . . 4-18
D. Contractor Reporting . . . . . . . . . . . . . 4-18

4-6 Change Control . . . . . . . . . . . . . . . . . 4-19

\section{LIST OF ILLUSTRATIONS}

Figure

$\underline{\text { Title }}$

Page

2-1 NWTS Program Responsibility Hierarchy . . . . . . . . . . . . . . . 2-3

2-2 OWI Organization . . . . . . . . . . . . . . . . . . . . . 2-4

2-3 Terminal Storage Program Schedule . . . . . . . . . . . . . . 2-9

2-4. Plant Development and Operations Schedule . . . . . . . . . . . . 2-11

3-1 WBS Development． . . . . . . . . . . . . . . . 3-3

3-2 OWI Work Breakdown Structure (WBS) . . . . . . . . . . . . . . . 3-5

3-3 Planning and Control Cycle. . . . . . . . . . . . . . . . . 3-7

4-1 กWI Work Breakdown Structure Form . . . . . . . . . . . . . . 4-3

4-2 OWI Status Record . . . . . . . . . . . . . . . . . . . 4-6

4-3 Output Report \#1.......................... 4-12

4-4 Output Report \#2 . . . . . . . . . . . . . . . . . . . . 4-13

4-5 Status Reporting/Problem Identification Concept . . . . . . . . . . . . . 4-16

4-6 Schedule Status Report ....................... . 4-20 
SECTION I

INTRODUCTION

\section{1-1 BACKGROUND}

The National Waste Terminal Storage (NWTS) Program was initlated by the United States Energy Research and Development Administration (ERDA). It is the responsibility of the ERDA Division of Nuclear Fuel Cycle and Production (DNFCP), and is coordinated by the ERDA Oak Ridge Field Office (ERDA/ORO).

In May 1976, the Union Carbide Corporation - Nuclear Division (UCC-ND), at the direction of the ERDA/DNFCP, established the Office of Waste Isolation (OWI) to assume the responsibility for the NWTS Program Management.

\section{1-2 NWTS PLANNING AND CONTROL SYSTEM OBJECTIVE}

The objective of the NWTS program planning and control system is to provide the information necessary for timely and effective OWI management decisions related to the NWTS Program including the formallzed mechanisms for:

- Defining the NWTS program in a disciplined, structured manner from highlevel summaries to discrete manageable work packages for which cost and schedule budgets can be established and performance responsibillty assigned 
- Providing program life cycle summary and detail, cost and schedule Information to satisfy management requirements

- OWI Internal and contractor reporting which will provide the necessary data to quantify dollars expended and work accomplished in relation to planned expenditures and progress

- Providing OWI management with program status in terms of summary and detailed cost and schedule information

- Timely identification of problems for management resolution

- Providing the information necessary to satisfy reporting requirements external to OWI.

\section{$1-3 \underline{S C O P E}$}

This manual provides the description of the NWTS Planning and Control System that will be implemented by OWI to satisfy the above objective. It contains:

- A brief description of the NWTS program in order to define the environment within which the system must function

- An overview of the system, and the concepts and techniques that were utilized in its development

- OWI implementation on the NWTS Program. 
SECTION II

NWTS PROGRAM DEFINITION

\section{2-I NWTS PROGRAM OBJECTIVES}

The NWTS program has two levels of complimentary objectives:

A. ERDA

- The Program will "provide multiple terminal storage sites for commercial radioactive waste in a time frame that assures nuclear power is a viable energy option."

- The program will "provide capability to safely store radioactive waste shipped to ERDA as required by 10 CFR50, Appendix F and proposed changes to 10rFR20."

B. OWI

The OWI objective for the NWTS program is "to provide facilities in various deep. geologic formations at multiple locations in the USA which will safely dispose of the commercial radioactive waste which must be delivered to a Federal Repository for terminal storage." 


\section{2-2 ORGANIZATION/RESPONSIBILITIES}

\section{A. OVERVIEW}

There are three organizational entities involved in the NWTS Program; ERDA/DNFCP, ERDA/ORO, and OWI. The primary responsibilities of each organization are:

1. $\underline{\text { OWI }}$

OWI is responsible for the "hands on" program and contract management of the NWTS Program.

2. ERDA/ORO

ERDA/ORO is chartered to monitor the NWTS Program and provide coordination throughout ERDA and the various organizations involved in the program.

3. ERDA/DNFCP

ERDA/DNFCP is responsible for setting NWTS Program objectives and to formulate and secure budgets and funding for the program:

Figure 2-1 portrays this relationship.

\section{B. OWI ORGANIZATION/RESPONSIBILITIES}

The Office of Waste Isolation Organization, figure 2-2, has been delegated major responsibilities in order to meet the NWTS Program objectives. There are seven major areas of responsibility given to OWI:

- Develop Program Plans and Alternatives

- Formulate Program Budgets

- Technical Program Coordinations

- Contract and Program Management

- Technical and Financial Reporting

- Information and Program Review Meetings

- Public Affairs Activities. 


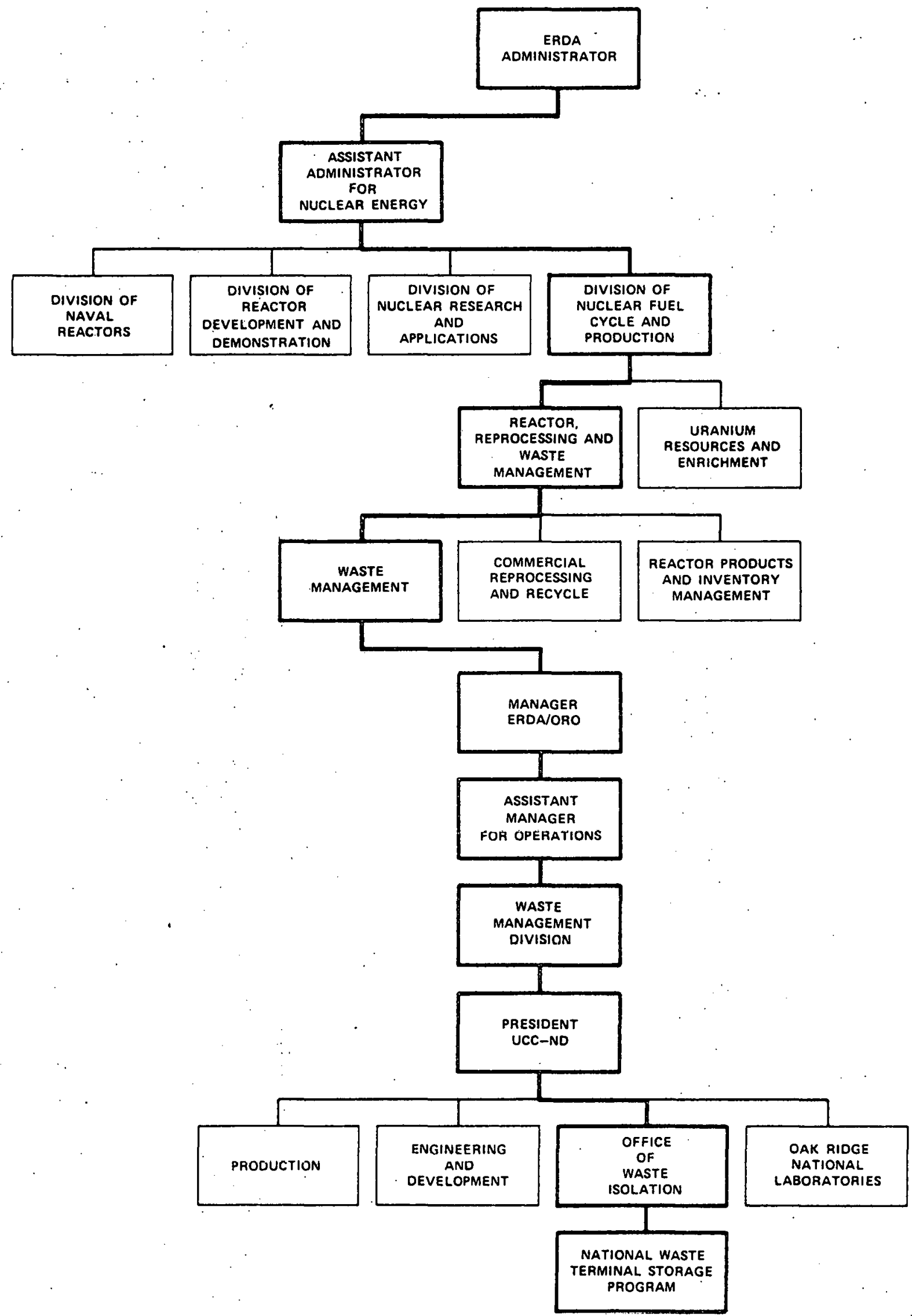

Figure 2-1. NWTS Program Responsibllity Hierarchy 


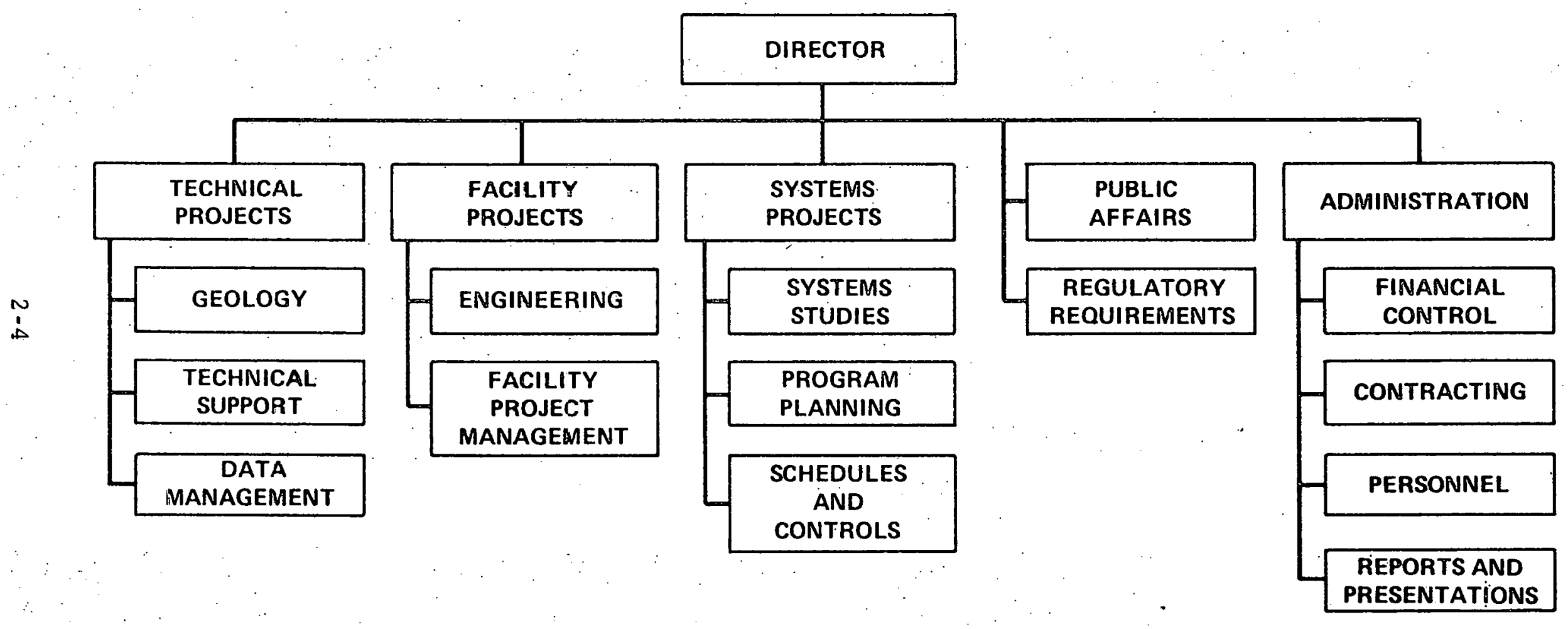

Figure 2-2. OWI Organization 
C. ERDA/ORO

The Oak Ridge Manager (ERDA/ORO) and his staff are the next management tier of responsibility. As stated before, ERDA/ORO program responsibility is basically coordination of the NWTS among the several organizations involved with the effort. Therefore, there are five major functions with which ORO is charged:

- Program Coordination

- Federal Interagency Agreements

- Participation of ERDA Fleld Organizations

- Facllity Design and Construction Contracts

- Administer UCC-ND contract.

D. ERDA/DNFCP

The final tier of Management is the Division of Nuclear Fuel Cycle and Production. This ERDA division is charged with NWTS policy and funding. DNFCP has five areas of policy and resource management responsibilities:

- Policy formulation

- Program Objectives and Definitions

- Providing Overall Direction for Program Management

- Approving Key Technical Decisions

- Final Determination of Budget.

\section{2-3 TECHNICAL APPROACH}

A. OVERVIEW

Technical Studies envision seven activities which will eventually lead to site selection and plant operations:

- Identification of Formations of Interest

- Reconnaissance Survey 
- In Situ tests

- Area Studies

- Detailed Confirmation Studies

- Pllot Plant Operations

- Conversion of the Pilot Plant into a Federal Repository

\section{B. SEQUENCE FOR TERMINAL DEVELOPMENT}

\section{Identification of Formations of Interest}

In the process of 1dentifying formations of interest, a revlew is made first based solely on the general knowledge of the geologic properties and/or fundamental properties of the rock type involved. If the review is promising, a reconnaissance survey is undertaken. This step has already led to the identification of salt, argillaceous, crystalline rock and carbonate rock formations as formations of interest. However, others may also be identified in the future.

2. Reconnaissance Survey

The purpose of the reconnalssance survey is to collect all the avatlable data on those properties and characteristics of the identified formation needed for waste disposal considerations. This information provides a regional evaluation of the potential for utilization of the formation for waste disposal and may include (1) structure, stratigraphy, depth, and thickness; (2) hydrology: (3) mineralogy/petrology; (4) natural resources; and (5) general surface characteristics. Based upon the information compiled at this stage, the prospects for the formation are evaluated and reviewed, and a number of smaller, perhaps "county size", regions are identified for further geologic area studies.

\section{3: In Situ Tests}

Once the formation is identified as a possible candidate for waste disposal, a set of in situ experiments are conducted in parallel with other geologic 
studies ranging from simple electrical heaters placed into holes in exposed surface outcrops of the formation to extensively instrumented vault tests in excavations speclally constructed at the expected depth of the pllot plant. In general, the vault tests are constructed to permit tests with both electrical heaters and/or canisters of simulated waste which are removed at the conclusion of the experiment. They provide extensive information on the physical behavior of the rock, the waste canister, as well as the stability of the underground layout. In situ tests have already been completed for salt formations, but still have to completed for other formations of interest.

\section{Area Studies}

The geologic area studies that follow the reconnalssance survey are designed to develop new and specific data in the areas of interest. These studies include (1) core drilling at a density of perhaps 6-10 Holes per 1,000 square miles to obtain adequate definition of the important subsurface characteristics of the formation, (2) field geologic mapping, (3) hydrologic studies, (4) geophysical surveys and (5) other geologic studies. The selection by OWI and ERDA of spectfic locations for more detailed confirmation investigations and the final selection of pllot plant sites will be firmly based on all these reviews as well as public comments obtalned during public progress reports.

\section{Detailed Confirmation Studies}

The detailed confirmation studies are directed toward specific locations of perhaps 2-5 square miles each. The investigations involve primarily the drilling and testing of four or more core holes at each location, plus the continuation of any specific geologic studies for which the previous results were inadequate to evaluate the suitabllity of the locations. The results of this phase of the investigation is to determine which locations fully qualify for consideration as pilot plant sites. 
6. Ptlot Plant Operations

After adequate review, a pilot plant site will be selected and a pilot plant constructed to evaluate the handling and storage operations using actual canisters of high-level waste and to confirm all design calculations. The Initial pilot plant will consist of surface handling equipment and under- ground excavations which are portions of the full-scale facllities. Experiments will be performed to test retrievability devices, emplacement concepts, and, in general, evaluate the stability of the underground workings. The data obtained during the initial pilot plant operations will be used to design the expanded pilot plant which will be operated untll it has successfully demonstrated that: (1) it can safely recelve, emplace and store high-level waste at the design rate, and (2) no anomalles in the geologic formation have been found.

7. Conversion to Federal Repository

The conversion of the facility to a Federal Repository will occur when sufficient data has been gathered to obtain the required licenses from NRC. This will be done at the earliest opportunity. When the facllity is converted to a Federal Repository, the main change would be to drop the retrievability option and to backfill and seal the storage rooms.

\section{MA3TER BCHEDULES}

1. Program Schedule

The Terminal Storage Program Schedule is shown in tigure 2-3, Terminal Storage Program. The above seven activities are shown in this program schedule for the pilot plant and the five plants thereafter. The key point of the schedule is the start of the terminal storage demonstrations in 1985 . The pilot plant is then followed by the other plants which are envisioned to become operational later on. 
TERMINAL STORAGE PROGRAM

(Calendar Year)

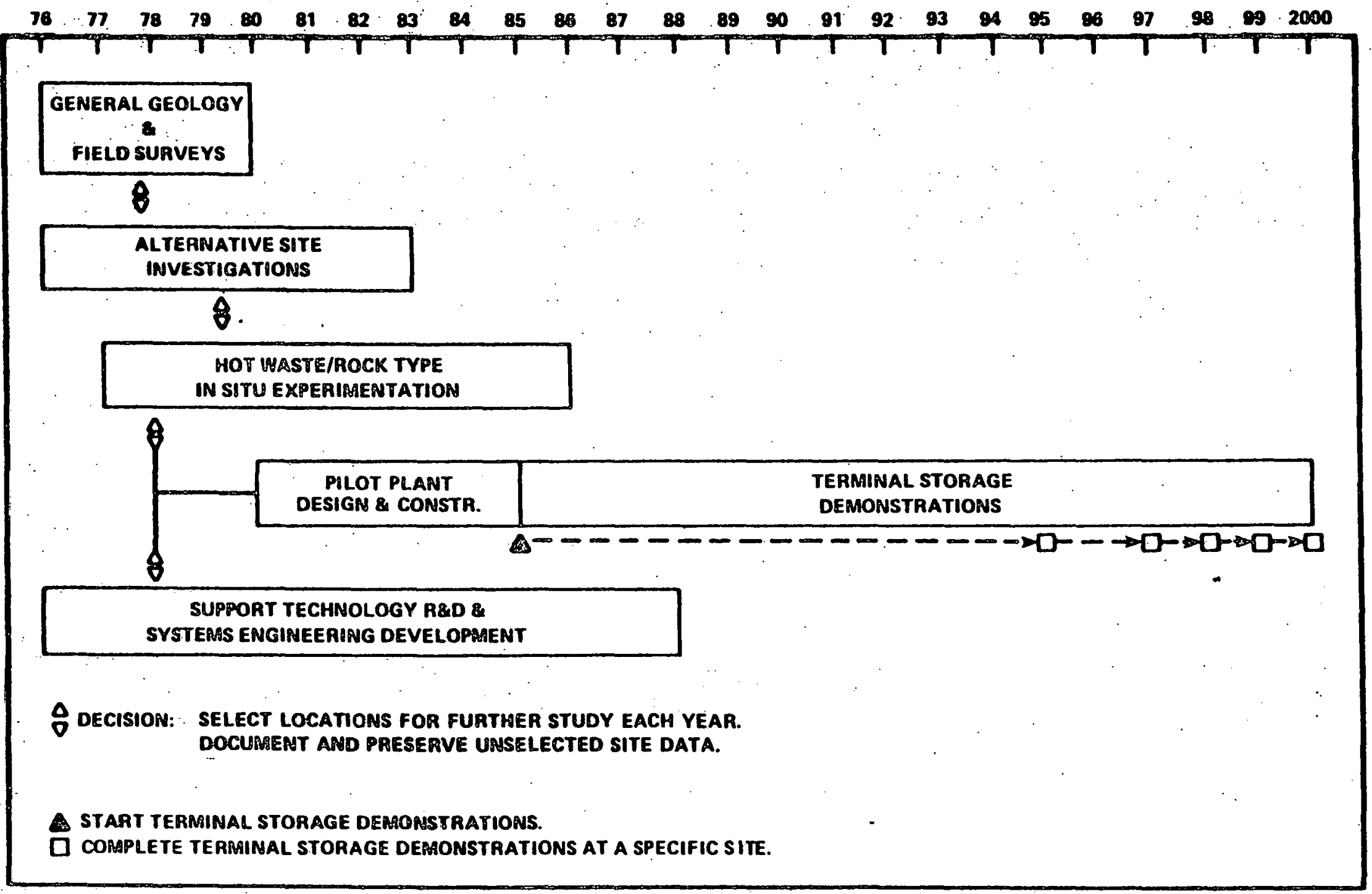

Figure 2-3. Terminal Storage Program Schedule 
2. Individual Plant Development and Operations Schedule A more defined schedule of development for each plant 1s derived from the NWTS Program Schedule. Figure 2-4 shows the six proposed plants as each of their individual activities would begin with General Geology and Field Surveys, denoted by the black triangles, and finish with partial and expanded operations. 


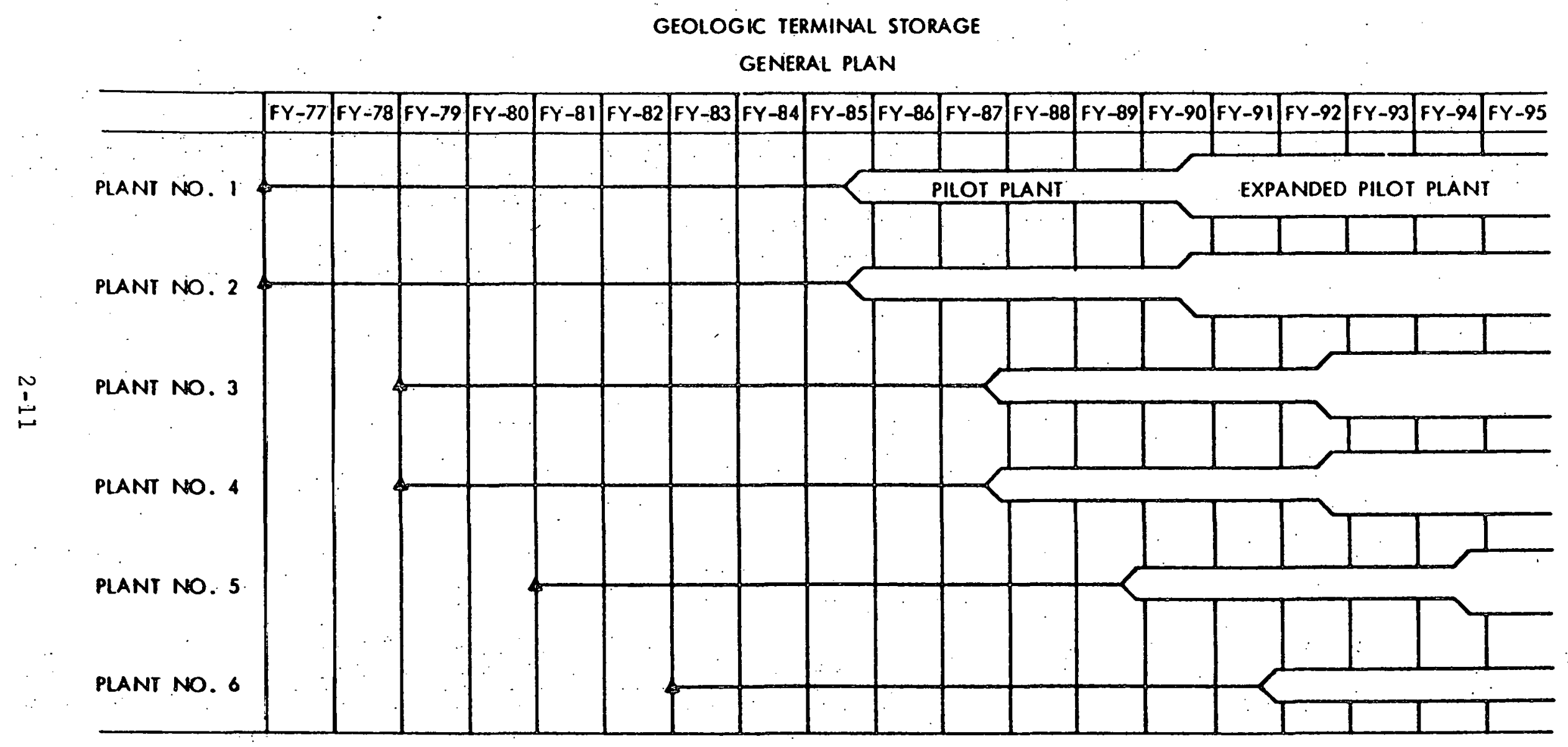

Figure 2-4. Plant Development and Operations Schedule 
SECTION THREE

SYSTEM DEFINITION

\section{3-1 OVERVIEW}

The NWTS Planning and Control System manual, as designed and Implemented by OWI, will include the following program and project management techniques:

- Work Breakdown Structure (WBS)

- Planning (Schedules/Budget)

- Performance Control

- Status Reporting

- Problem Identification

- Contractor Control

- Change Control.

\section{3-2 WORK BREAKDOWN STRUCTURE CONCEPT}

The WBS technique requires the identification of the major end items of the NWTS program with successive subdivision of each end item into increasing detalled categories and sub-categories of products and work. The completed WBS will define the total program effort in terms of manageable elements or packages of work which are the responsibility of the various OWI organizational entities. The WBS will then have identified the various levels and descrete elements of work to enable:

- The identification of any functional interfaces that might exist between the elements. 
- The scheduling of tasks in logical sequence.

- The budgeting of funds in consonance with task schedules.

\section{3-3 NWTS WORK BREAKDOWN STRUCTURE}

The NWTS Work Breakdown Structure is a product-orfented task hierarchy of all of the work to be performed in accomplishing the program objectives. The products are hardware, software, support services, tests, documentation, and other quantified elements. The Program Summary levels consist of Level zero, the NWTS Program, and Level 1 elements such as Program Management, Geologic Studies, Technical Support and Engineering Studies. Further definition and structuring of the work under each of the Level 1 elements produce the Project Summary Elements normally at Level 2 through 5 depending on the subdivision of work definitions practicable from each Level 1 Program element. The number of levels in the task hierarchy depends upon the scope and complexity of the individual projects. Where the project involves contract effort, the portion of the WBS relating to the contract effort is developed in two segments; (1) the Project Summary WBS, and (2) the Contract WBS. Figure 3-1 describes the sequence of WBS development.

\section{A. PROJECT SUMMARY WORK BREAKDOWN STRUCTURES (PSWBS)}

Profect summary WBS will be prepared by OWI to identify the lower level elements unique to the various projects. The PSWBS will normally contain project elements through at least the third level. OWI will select project elements from the PSWBS for assignment to contractors. The contractors will then develop their contract Work Breakdown Structures (CWBSs) to lower levels elements.

\section{B. CONTRACT WORK BREAKDOWN STRUCTURES (CWBS)}

A complete WBS for a contract will be developed and used by the contractor in accordance with the contract statement of work (SOW). The CWBS is comprised of, and based upon the selected PSWBS elements included in the Request for Proposal, and the extensions of these elements by the contractor to cover the lower levels of the WBS. Approval of the CWBS will be negotiated by OWI with the selected contractor. The agreed upon CWBS provides the common denominator for communication between OWI and the contractor for work planning, control and contract reporting. 


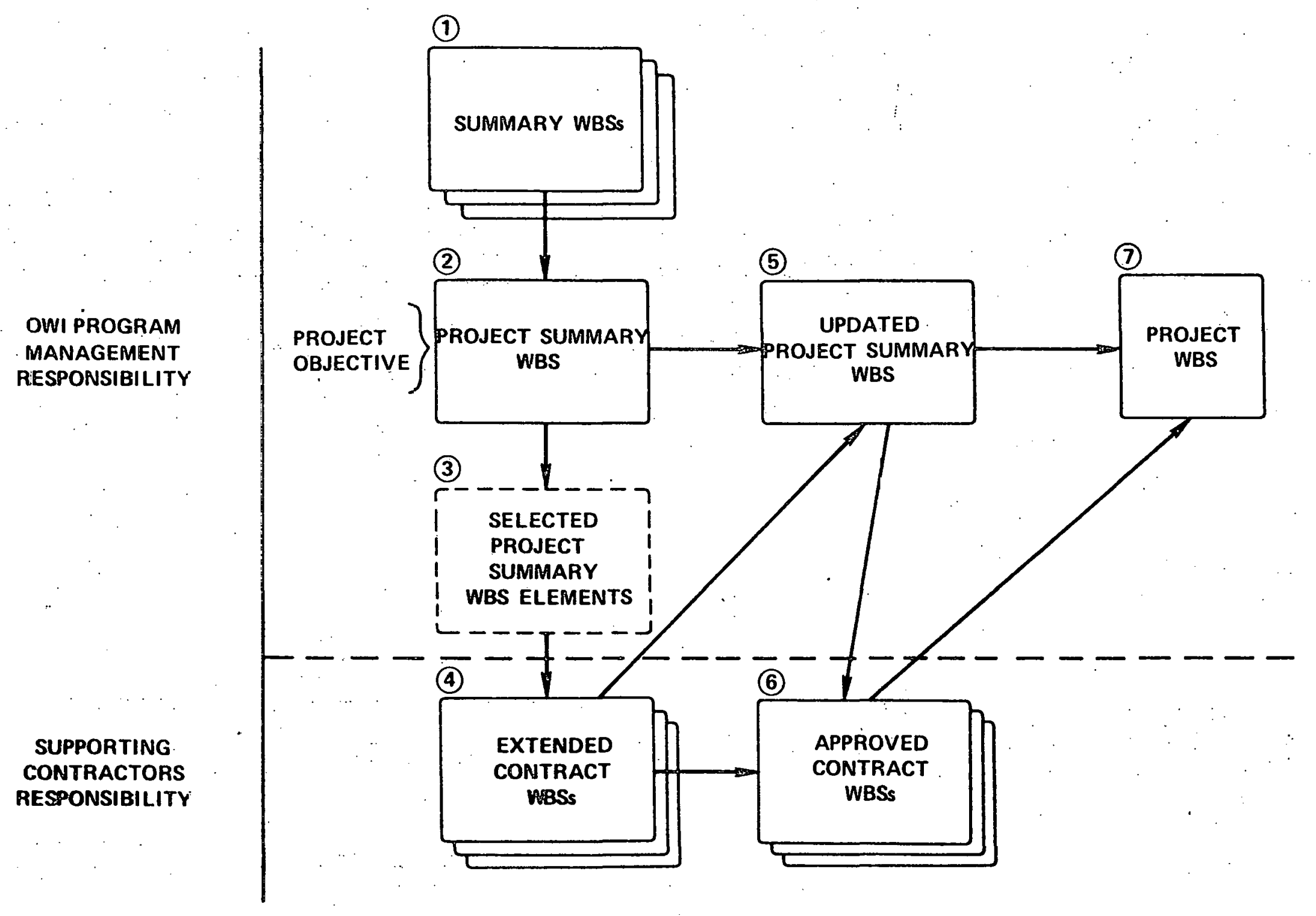

Figure 3-1. WBS Development 


\section{PROJECT WORK BREAKDOWN STRUCTURES}

OWI will construct the Project WBS by combining the approved CWBSs for all supporting contracts and the updated PSWBS. All levels of the CWBSs need not be included in the OWI Project WBS. The Project WBS will be maintalned and revised to incorporate changes throughout the life of the project to ensure traceability of the work efforts. An amplification of the WBS development is contained in ERDA Handbook 0805.3 Part 1 Work Breakdown Structures, and the ERDA Reactor Development and Demonstration (RDD) Performance Measurement System WBS Guide RDD/PMS - 6 .

D. NWTS WBS IDENTIFICATION NUMBERING

Figure 3-2 defines the NWTS WBS numbering system for element identification.

1. Program/Summary WBS

The highest Program Summary WBS Level is designated Level " 0 " which represents the NWTS Program (1100).

The next lower Program Summary Level is designated Level 1 which contains the major program elements of the NWTS Program:

1110 Program Management

1120 Geological Studies

1130 Technical Support Activities

1140 Engineering Projects

1150 . Facility Projects

1160 System Studies

1170 Regulatory Affairs

1180 Public Affairs

2. Project Summary Levels

The Project Summary Levels, normally 2 through 5, are obtalned by further definition of the work within each element of the Program summary Level 1. For example, as shown in figure 3-2, 1130 Technical Support is further divided into elements which include 1131 Heat Transfer, 1132 Waste/Rock Interactions, and 1133 Rock Mechanics. Selecting 1133 for further work 


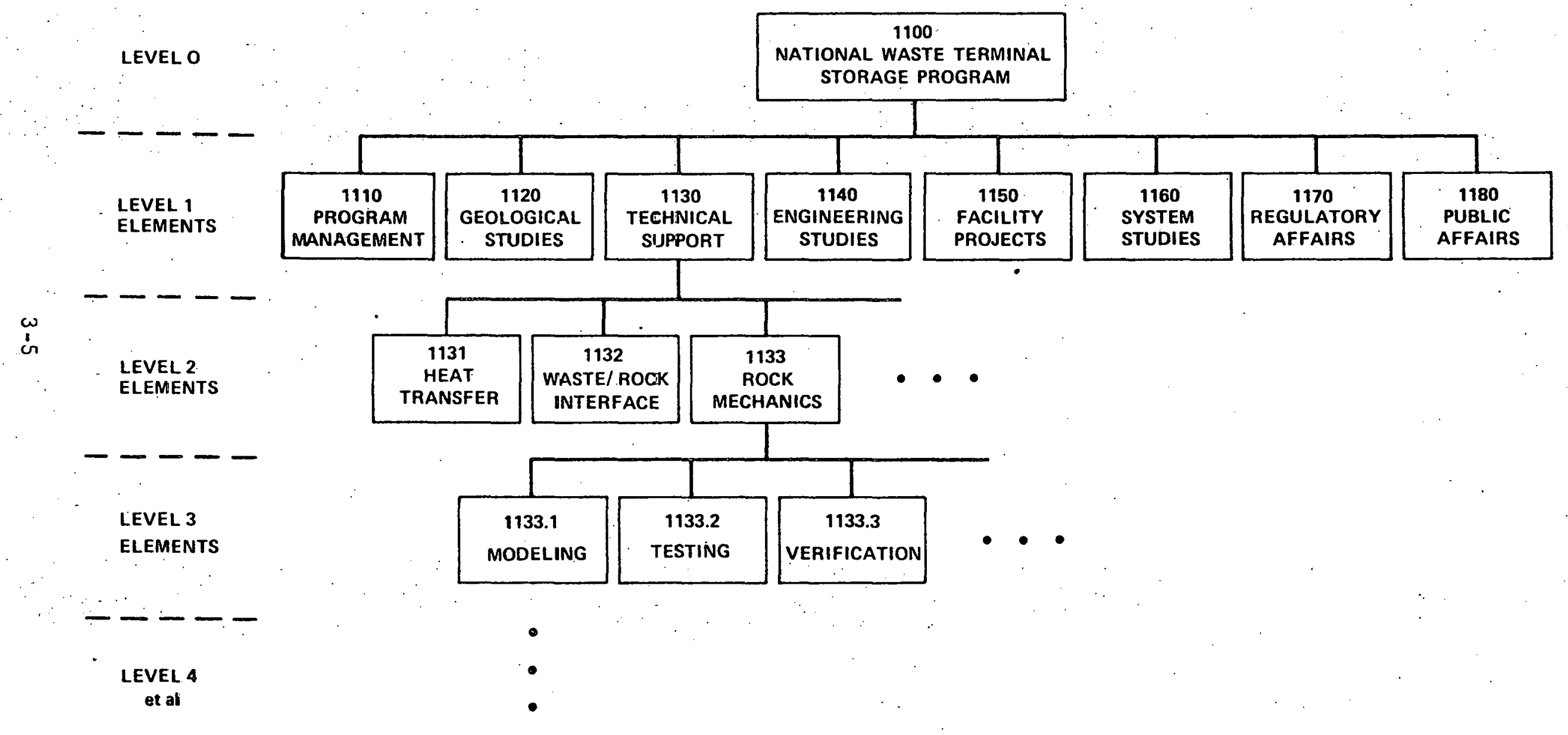

Figure 3-2. OWI Work Breakdown Structure (WBS) 
breakdown, the Level 3 elements would include 1133.1 Rock Mechanics Modeling and 1133.2 Testing and 1133.3 Verification.. A typical Level 4 element iteration would appear as 1133.3 .1 et al.

\section{3-4 PLANNING}

OWI will conduct the planning of the NWTS Program utillzing the WBS concept for an adequate definition of the work to be accomplished to develop schedules, budgets and performance control. OWI has developed NWTS master schedules and associated budgets utilizing this technique. These schedules and budgets will be amplified and revised on a continuing basis as illustrated in figure $3-3$, Planning and Control Cycle.

\section{A. ROLLING WAVE CONCEPT}

The "rolling wave" planning concept will be used by OWI. According to this concept, work is planned in finite but sizable increments at the outset of the program. These planning increments form the basis for work authorization, budgeting, and master scheduling. As the program progresses, near term work is defined and planned in more detail. The effect of this concept will be the avallability of a detailed definition for the work to be accomplished in the near term (F1scal Year), larger elements of work defined for intermediate time periods (one to flve years) and summary type detall for those time periods beyond the intermediate range.

\section{B. SCHEDULES}

\section{The WBS and Scheduling}

The WBS affords a framework for the aggregation of schedule information by WBS elements to establish overall and detailed schedules. Schedules will become progressively more accurate as plans are developed in greater detail and more information is avallable to OWI. The scheduling techniques that will be utilized by OWI are described in the following paragraphs.

a. Milestone Schedules

The milestone scheduling technique focuses on the sequential achleve ment of significant actions necessary for successful completion of the project objectives. It provides the schedules and sequential relationships among major activities and events of the project effort. 


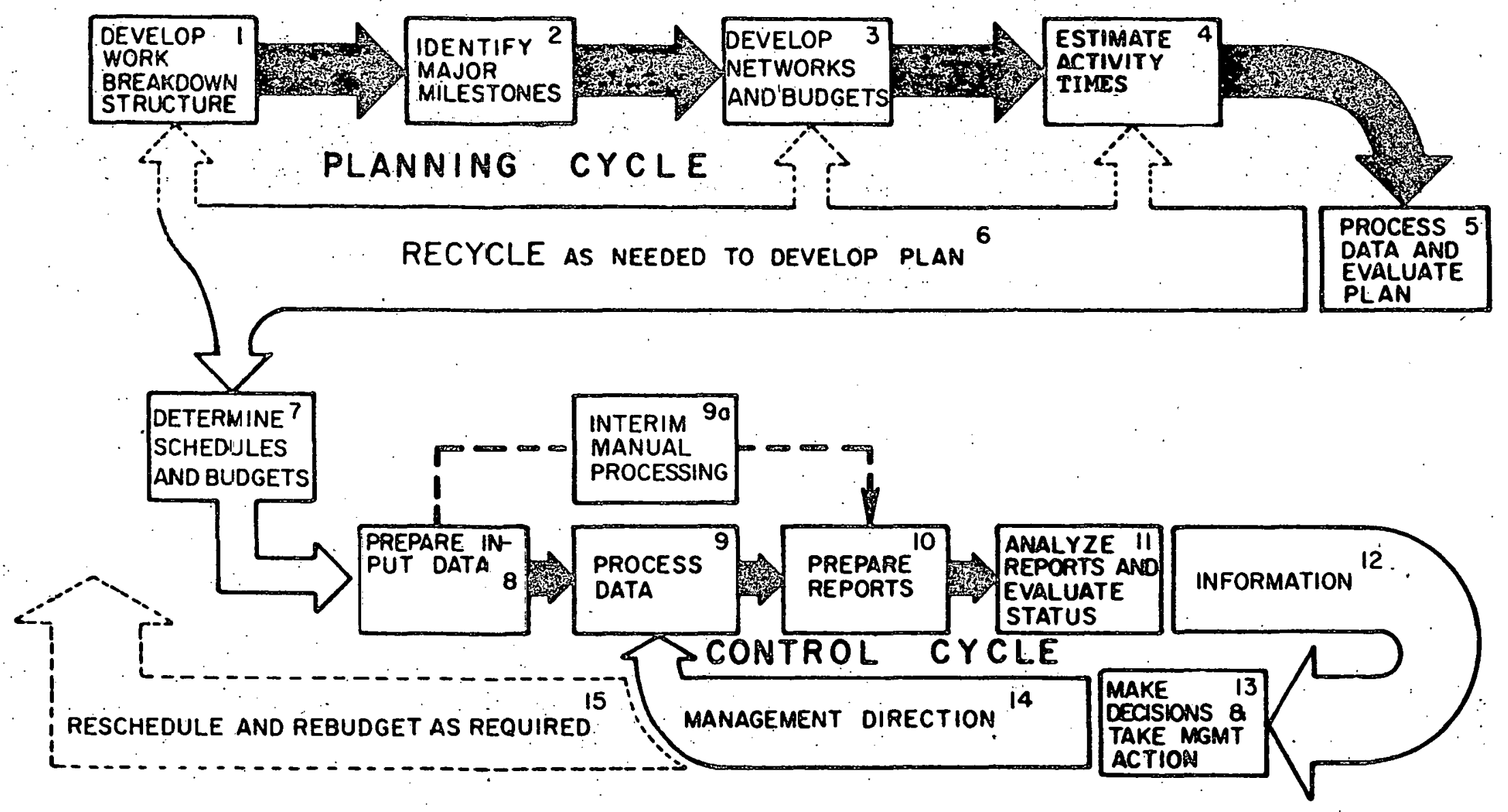

Figure 3-3. Planning and Control Cycle 
b. Network Scheduling

Network techniques (such as PERT and CPM) deplet the interrelationships and interdependencles of the planned project activities and events and evaluate the critical path (sequence) of activity completion. The activities and events depicted in the network should be clearly related to both the WBS and the project milestones. The essential purpose of network methods is to develop an explicit plan for the program which recognizes the logical sequences in which the individual activities must be performed. On the basis of this plan, it then becomes possible to analyze the project in terms of the total time required and potential constraints. The network method will also be used as a control device for comparing actual progress with scheduled progress and evaluating possible corrective action if required.

c. Gantt Charts

Gantt charts identify individual task and job orders, depicting their scheduled and actual progress against time. The tasks that they depict are derived from the lowest "work package" element of the WBS. Thus, they represent the ultimate breakdown of the project work to the detailed tasks (and manpower) of a unit or individual for accomplishing the work package effort. However, the Gantt chart is essentially a reporting display chart. The milestones and events of the Gantt chart can become highly accurate schedule reports when they are based on the information provided from a network planning and control technique.

d. Line of Balance (LOB)

The Line of Balance (LOB) techniques provide a means of controlling detailed and repetitive production processes. The application of the LOB technique is almost entirely restricted to projects involved in the production and delivery of quantities of hardware, or a repetitive processes on a time-phased schedule extending over a prolonged period of time. 


\section{e. Interface Milestone Management}

Interface Milestone Management is a technique for 1dentifying and managing the interface events and milestones that should be scheduled to accomplish the functional interfaces that are identified between the tasks of two or more subsystem managers. An appropriate network based planning and scheduling technique will help ensure that these highly critical events are accomplished within schedule.

\section{BUDGETING}

Based upon the work definition provided by the WBS and the time orientation supplied by the scheduling function, OWI will prepare the necessary budgets for the NWTS Program.

To fulfill the budgeting requirements, the technique to be utilized is to estimate costs at the lowest levels of the WBS and summate upwards to the required levels. Budgets will be prepared by OWI Managers in accordance with ERDA directives. Budgets will be in consonance with the U.S. Government Fiscal Years commencing in October and running through the following September, and will include two cost categories which are Plant and Capital Equipment (P\&CE) and Operating Costs (O\&M).

\section{3-5 PERFORMANCE CONTROL}

\section{A. INTRODUCTION}

The fundamental elements of performance control for the successful management of $a$ program are cost, schedule and technical performance control. In the past these parameters were controlled by a comparison of planned cost, schedule and technical progress versus actuals. This basic technique has been enhanced by the "earned value" concept, which will be utilized by OWI on the NWTS Program.

\section{B. EARNED VALUE CONCEPT}

This concept utilizes three measurement parameters to quantify the cost and schedule progress against planned or budgeted work, in terms of dollars. These elements are:

1. Budgeted Cost for Work Scheduled (BCWS)

This is the time-phased budget plan (baseline) which represents the contract work plan. 
2. Budgeted Cost for Work Performed (BCWP)

This is referred to as the "earned value" or the planned value for work performed.

3. Actual Cost for Work Performed (ACWP)

This parameter consists of the direct and allocated indirect costs applicable to the contract.

The relationship of these parameters to the terminology utilized by OWI or the OWI Status Record, figure $4-2$, is as follows:

Earned Value Concept

BCWS

BCWP

ACWP
OWI Status Record

Plan

Progress

Actuals

\section{COST AND SCHEDULE V VARIANCES}

1. Cost Variances

Utilizing the "earned value" technique, cost variances are computed by subtracting the ACWP (Actuals) from the BCWP (Progress) with the answer being in a positive or negative variance. Thresholds of acceptable cost variances for each reporting level will be established by OWI, thereby facilitating the management by exception technique.

2. Schedule Variances

Schedule Variances will be measured utilizing both the "earned value" concept (dollars) and normal "time" status measurement techniques. This is neces sitated by the fact that "dollar" only controls may obscure work sequence problems and failure to meet specific milestones.

a. Schedule Variances-Dollars

Utilizing the "earned value" concept, schedule variances in terms of dollars will be calculated by subtracting the BCWS (Plan) from the BCWP (Progress). with the answer being in a positive or negative schedule variance. Thresholds of acceptable variances will be established by OWI management. 
b. Schedule Variances - Time

OWI will utilize various scheduling techniques to establish the status of schedules in terms of time. These will include milestone charts; schedule narratives, networks (PERT/CPM), Gantt charting and Line of Balance.

\section{INTERPRETATION OF EARNED VALUE RELATTONSHIPS}

The following table provides examples of the management visibility afforded OWI by utilizing the "earned value" concept.

\begin{tabular}{cccll}
$\begin{array}{c}\text { Schedule } \\
\text { Variance }\end{array}$ & \multicolumn{2}{c}{$\begin{array}{c}\text { Cost } \\
\text { Variance }\end{array}$} \\
BCWS & BCWP & ACWP & \multicolumn{2}{c}{ DESCRIPTION } \\
$\$ 1$ & $\$ 1$ & $\$ 1$ & On Schedule & On Cost \\
$\$ 2$ & $\$ 2$ & $\$ 1$ & On Schedule & Under Cost \\
$\$ 1$ & $\$ 1$ & $\$ 2$ & On Schedule & Over Cost \\
$\$ 1$ & $\$ 2$ & $\$ 2$ & Ahead of Schedule & On Cost \\
$\$ 1$ & $\$ 2$ & $\$ 3$ & Ahead of Schedule & Over Cost \\
$\$ 1$ & $\$ 2$ & $\$ 1$ & Ahead of Schedule & Under Cost \\
$\$ 3$ & $\$ 2$ & $\$ 1$ & Behind Schedule & Under Cost \\
$\$ 2$ & $\$ 1$ & $\$ 3$ & Behind Schedule & Over Cost \\
$\$ 2$ & $\$ 1$ & $\$ 1$ & Behind Schedule & On Cost
\end{tabular}

Schedule Variance $=\mathrm{BCWP}-\mathrm{BCWS}$

Cost Variance $\quad=B C W P-A C W P$

\section{E. TECHNICAL ACHIEVEMENT}

A.key to effective cost/schedule control is correlation of technical achievement with accomplishment of the work effort. If the Project Summary Work Breakdown Structure (PSWBS) and associated Contractor W/ork Breakdown Structures (CWBS) or contractual tasks, properly define the project and tasks, correlation is greatly simplified. In correlating cost, schedule, and technical performance, it is apparent that unfavorable cost or schedule conditions may be caused by technical difficulties. When this is the case, the quantitative information the contractor reports will be supplemented by narrative to explain the technical problem and its impact. 
As work on a contract progresses, the contractor will be required to determine the adequacy and quality of the work performed by inspections, tests, or other types of technical measurements. If the results are satisfactory and no corrective action is required, the work will be allowed to proceed. If, on the other hand, deficiencies are found, the contractor will be required to analyze the various alternatives for corrective actions, e.g., redesign, scrap and remake, and rework. When considering these alternatives, the impact on cost and schedule must be weighed in addition to the technical considerations. After one of the alternatives is selected as the desired course of action to correct the deficiencies, it will become necessary to plan the additional work and to change the schedules affected. In some cases, OWI may choose to provide additional budget to the responsible organization. Thus, there is a close relationship between technical achievement, as determined by inspection and test, and its impact on cost and schedule.

\section{3-6 STATUS REPORTING.}

\section{A. MEDIA}

The following media will be utilized by OWI Managers and contractors as appropriate for reporting the status of the NWTS Program and the projects therein.

1. Graphic Presentations

Graphic presentations will include the display of information from the Status Record, Schedule Status Reports (mllestone/Gantt charts), and Networks.

2. Narrative Reports

Narrative status reporting will include cost and schedule narratives and Problem Analysis Reports .

3. Program/Project Reviews

In addition to the above, Program/Project reviews will be scheduled on a regular basis both within OWI and with contractors. The intervals for these reviews will be determined by OWI management based upon the dollar value and/or criticality of task or tasks being reviewed. 


\section{B. REPORTING HIERARCHY}

In ascending order, the reporting hlerarchy commences with contractor reports to OWI. The next level of reporting is from OWI Managers to the Director, OWI. Based upon information contained in contractor reports and the internal OWI reports, the Director, OWI, reports externally to ERDA, UCC-ND or other organizations as required.

\section{3-7 PROBLEM IDENTIFICATION}

OWI managers will utilize the management by objectives and the management by exception techniques. The basic document utilized to identify problems is the OWI Status Record. OWI managers will establish variance tolerances for use by OWI Management and contractors. When status reporting in the system's hierarchy indicate variances exceeding tolerances, a Problem Analysis Form will be completed.

\section{3-8 CONTRACTOR CONTROL}

During the life cycle of the NWTS Program numerous contractors will be solicited to provide a great variety of services. In order that OWI can exercise sufficient control over contractor performance, it is mandatory that the individual contractor's planning and control systems be interfaced into the NWTS system.

\section{A. CONTROL METHOD CRITERIA}

Two methods of control will be exercised by OWI depending upon the nature of the contracted effort. Those contracts that require stringent control will be selected by OWI in accordance with the following criteria:

- Contracts with a total value in excess of $\$ 500,000$

- Contracted efforts that are of a technical or schedule nature critical to the NWTS Program as assessed by OWI management

- As specifically directed by the OWI Program Director or his designated representative (s) 
- Contracts other than fixed price or fixed price with escalation. All other contracts including flxed price incentive are candidates for control method number 1 .

\section{B. CONTROL METHOD NUMBER ONE}

In-depth control will be exercised by OWI for those contracts that are of a type, expenditure level, and/or criticality to the NWTS program as established by the defined criteria, to warrant detailed OWI management visibility. In these instances. OWI will specify in the Request For Proposal (RFP) that the contractor must adhere to the major concepts and techniques of the NWTS system described in this manual and report status utilizing the OWI forms at control levels approximating $\$ 50,000$ and 3 months in duration. This status information will be integrated into the NWTS system.

\section{CONTROL METHOD NUMBER TWO}

Those contracts that do not warrant in-depth OWI management visibility, based upon the defined criteria, will be controlled at significantly higher levels of expenditures and task durations. These contractors will still be required to utilize the OWI status reporting forms to facilitate inclusion of the performance information in the NWTS system.

The rationale for this variable level of control approach is that a majority of the contract dollars and critical tasks will be awarded to relatively few contractors. Utilizing the two alternative methods, OWI can focus their management attention on a few relatively few contracts to exercise in-depth control over the majority of NWTS costs and mission critical efforts. The remaining contracts will receive the level of management attention warranted by their nature.

\section{3-9 CHANGE CONTROL}

All of the previous paragraphs in this section have described the concepts and techniques that will be utilized by OWI to establish structured, completely planned and controlled technical, cost and budget NWTS Program baselines, from 
which performance or progress can be accurately measured. If the integrity of the system is to be maintained, any changes to the baselines must be incorporated in a disciplined manner.

In order to obtain the degree of management discipline required to ensure the continuous validity of the established baselines, OWI will develop and implement a change control procedure that will:

- Provide complete definition of proposed changes

- Allow for the categorization and prioritizing of each proposed change

- Assure total impact assessment prior to approval request

- Schedule and track change processing

- Establish hierarchical approval criteria

- Control implementation

- Afford traceability.

It is planned that this initial planning and control system change control procedure will be an integral part of the eventual NWTS Program Configuration Management System. 
SECTION IV

SYSTEM IMPLEMENTATION

\section{4-1 IMPLEMENTATION PHASES}

The NWTS Planning and Control System is being implemented by OWI in three phases.

\section{A. PHASE I, MANUAL OPERATION}

The planning and control system will initially be operated manually and monitored continuously by OWI for necessary improvements and enhancements.

\section{B PHASE II, AUTOMATION}

Based upon the experience gained by the initial manual operation of the system, an automated version will be designed, tested and implemented by OWI. To ensure continuity, dual operations wlll be conducted as long as required.

\section{PHASE III, EXPANSION}

The automated system will be expanded to include specialized functions such as total project cost projections and simulation modeling techniques to add "what if" capabilities. 


\section{4-2 OWI WORK BREAKDOWN STRUCTURE FORM}

The OWI Work Breakdown Structure Form, figure 4-1, identifies the individual work elements with their associated budgets, schedules, responsibility, work orders, and start/stop dates. There are eleven major data element groups that make up the OWI Work Breakdown Structure Form. The following instructions are provided for completing the various elements.

1. WBS LEVEL; Area (1)

Enter the numerical designation for each element, indented to its correct level definition.

2. DESCRIPTION, Area (2)

Enter a brief description of each element. Start description immediately adjacent to the numerical designation.

3. ASSIGNED RESPONSIBILITY, Area (3)

Enter the name of the person responsible for the work element. Add the letters S.C. if the work is subcontracted.

4. WORK ORDER NUMBERS, Area (4)

Enter the work order(s) that will be used to collect actual cost for summary or lowest-level tasks. In some instances, more than one work order number may accumulate to one task, but a single work order number will never be divided between more than one task.

5. PERFURMANCE' MEASURE'ME'N'I CUUE (PMC), Area (5)

Enter the code of the performance measurement technique to be utilized to measure work progress on the particular task as defined on the lower portion of the form.

PMC 0 -Level of Effort

Some tasks associated with a program result in little tanglble product. An example of this is the project management function. It is necessary to control various efforts but it in itself does not produce a tangible product. 


\section{OWI WORK BREAKDOWN STRUCTURE FORM}

(1)

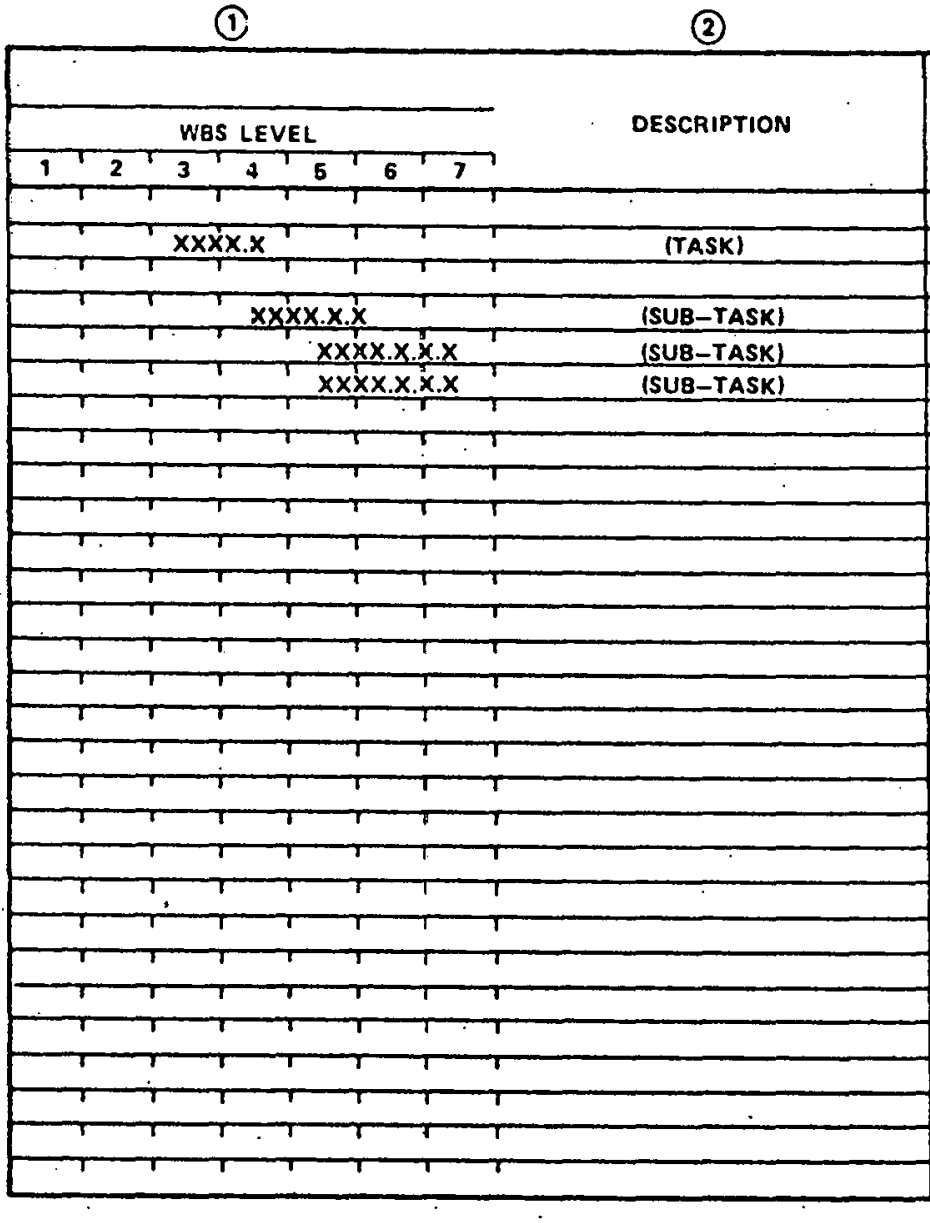

DATE:

- PMC - PEAformance MEASUREaENT CODE

O = LEVEL OF EFFORT

1. 50\% AT tASK START, 50\% AT COAPLETION

** indicate with Letters s.c. if job is subcointaacted.

(3)

(4)

(5) (6)

(7)

(8)

(9) (19)

\begin{tabular}{c|c|}
$\begin{array}{c}\text { ASSIGNED } \\
\text { RESP.: }\end{array}$ & $\begin{array}{c}\text { WORK } \\
\text { ORDER } \\
\text { NUMBERS }\end{array}$ \\
\hline
\end{tabular}

COMMITMENTS

P \& CE COSTS

OPERATING COSTS

TOTAL

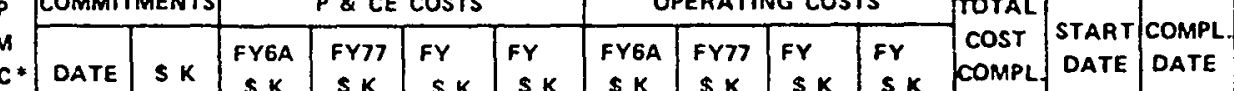
NESP. NUMBERS

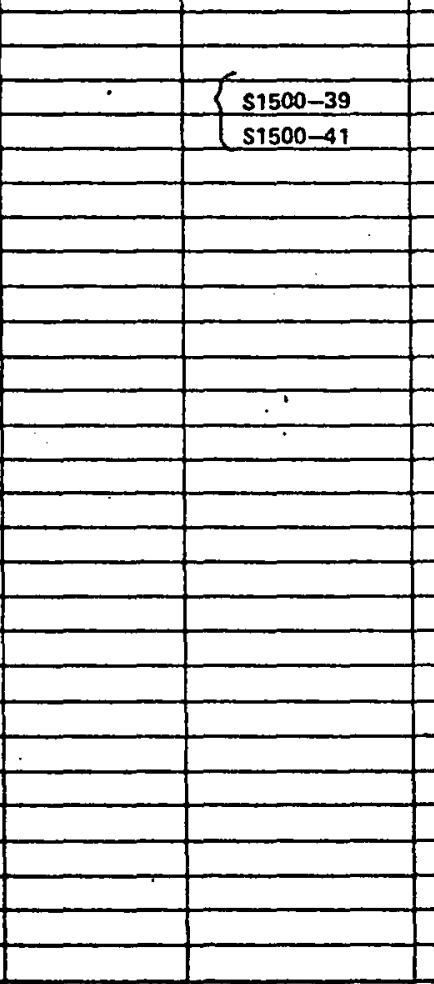

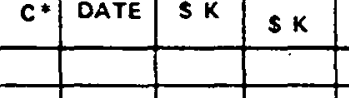

\begin{tabular}{|l|l|l|l|l|}
$S K$ & $S K$ & $S K$ & \\
\hline
\end{tabular}

\begin{tabular}{l|l|l|l|l|l|}
$\$ K$ & $\$ K$ & $S K$ & $S K$ \\
\hline
\end{tabular}

\begin{tabular}{l|l|l|} 
& & \\
\hline & & \\
\hline
\end{tabular}

\begin{tabular}{l|l}
1 & \\
\hline &
\end{tabular}

\begin{tabular}{ll|l|l|l|}
\hline & & & & \\
\hline & & & & \\
\hline & & & 13 & \\
& & & 13 &
\end{tabular}

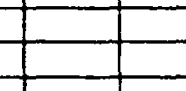

PREPARED BY

$2=0 \%$ AT START, 100\% AT COMPLETION

3 - DRAWING COUNT

4 - PERCENT COMPLETE
APPROVEO BY

$5=$

$6=$

$7=$

Figure $4-1 ;$ OWI Work Breakdown Structure Form 
The level of effort, measured by the expenditure of money, is the only feasible means for quantifying the level of work being accomplished.

PMC $1-50 \%$ At Task Start, 50\% At Completion

Certain work packages are of the type that merely starting the effort represents a significant accomplishment. Examples of tasks where starting is a significant step are drilling a bore-hole, preparing a facllity site, negotiating a contract or running an experiment. For tasks of this type it is justifiable to claim credit for a large percentage of the task's value as accumulated work progress once the task has begun, and to claim credit for the remaining percentage of the task's value once the task has been completed.

PMC $2-0 \%$ At Start, 100\% At Completion

The most objective and conservative measure of work progress is to report progress only when tasks have been completed. Assuming that tasks can be subdivided into very short work span profects, this technique of counting completions is very effective. It is the preferred technique used in the OWI Planning System for measuring work progress because it relles on evaluating completed work packages.

PMC 3 - Drawing Count

3

Traditionally in engineering design work, work progress has been measured by counting the number of engineering drawings completed for a project and comparing that number with the total number of drawings planned.

\section{PMC 4 - Percent Complete}

The objective measurement of some progress and some tasks is very difficult even if they eventually do result in a tangible product. It is difficult to identify examples of this, but one might be report writing. For such tasks, it is possible only to estimate, in a subjectlve manner, the percent age of the job that is finished. 
6. COMMITMENTS, Area (6)

Enter the procurement commitments and dates for each task.

7. PLANT AND CAPITAL EQUIPMENT (P\&CE) COSTS, Area (7)

Enter the P\&CE costs by the appropriate fiscal year.

8. OPERATING COSTS, Area (8)

Enter the operating costs by fiscal year.

9. total COSt at COMPLEtion, Area (9)

Enter the estimated total cost at completion of the task.

10. START/COMPLETE DATES, Area (10)

Enter the start and completion dates for each lowest level task.

11. DATE, PREPARED BY, APPROVED BY

Enter the date of preparation, identity of the person completing the form, and approval signature.

In summary, the OWI WBS form provides a detailed planning capability for each work element within the NWTS Program.

\section{4-3 OWI STATUS RECORD FORM}

The basic tool in the system for depicting the technical progress of the NWTS program is the "OWI Status Record", a sample of which is shown in figure 4-2. One of these records shall be maintained for each task by the cognizant task manager. This section gives explicit instructions for filling out the Status Record Form.

\section{A. OPENING THE RECORDS}

The following steps are to be followed to initiate a record.

1. "TASK DESCRIPTION" and "DATE"

a. Enter the WBS number of the task and its descriptive title.

b. Enter the date and the current year. 
OWI STATUS RECORD

TASK OESCRIPTION

$x \times x \times x$ DATE:-

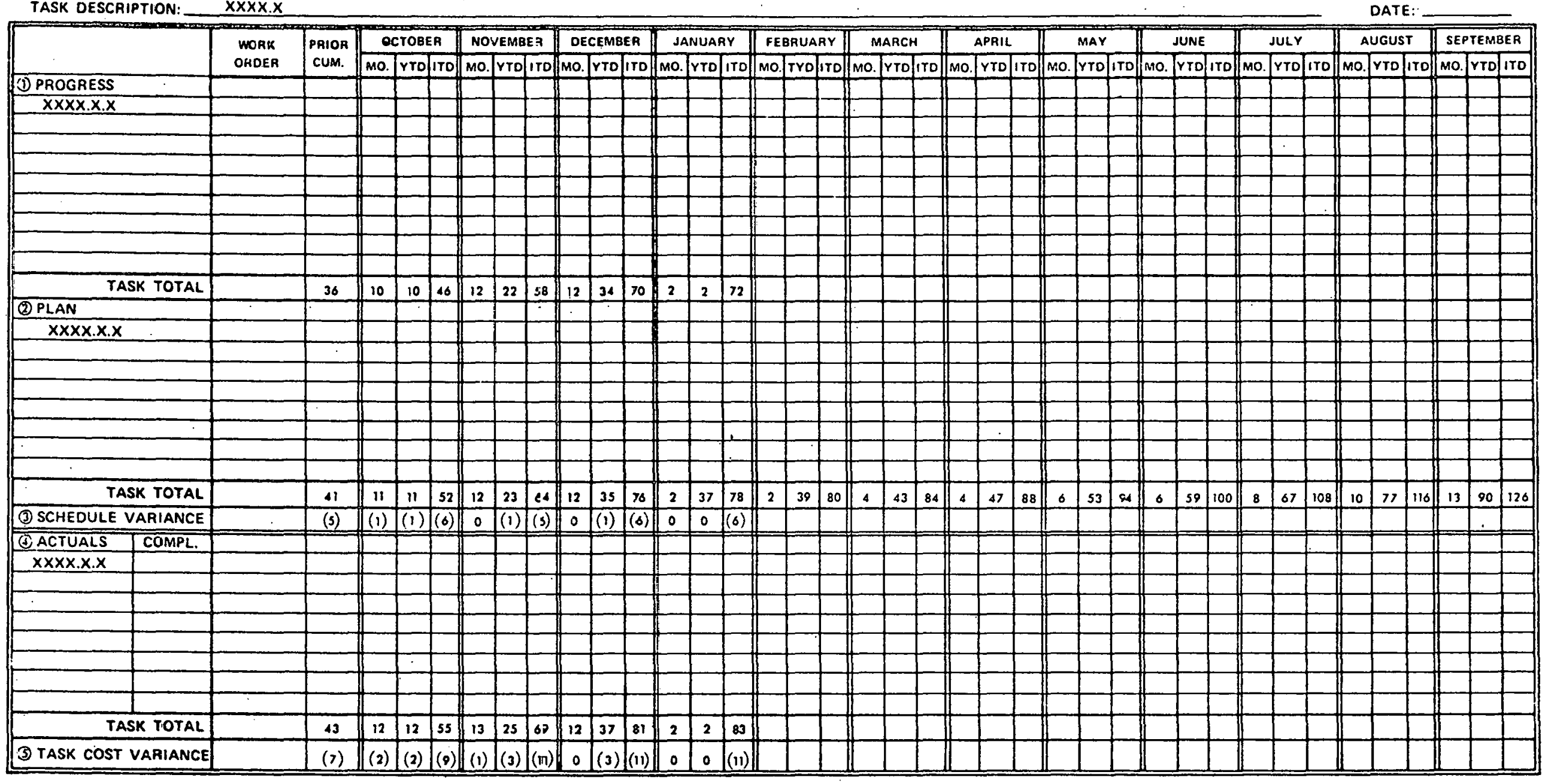
LISTING OF SUBTASKS AND DESCRIPTIONS

LISTING OF SUBTASKS AND DESCRIPTION
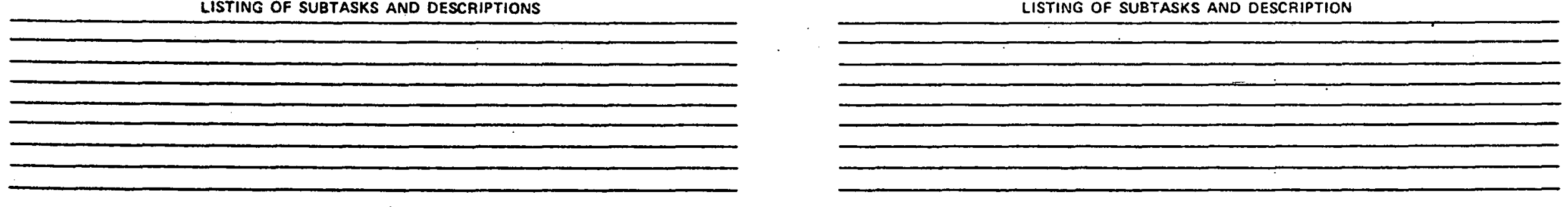

Figure 4-2. OWI Status Record 
2. "PROGRESS", Area (1)

a. In the first column list all WBS elements defined for the task, which are called "sub-tasks".

b. In the second column list the numbers of the respective work orders for the sub-tasks. Note that in the OWI system, more than one work order may accumulate to one task, but a single work order will never be divided between more than one task.

c. In the "PRIOR CUM" column, enter the cumulative budgeted costs for work performed on the total task and for each of its sub-tasks, through the preceding September. These numbers will be entered from the "ITD" column for September from the completed OWI Status Record for the preceding fiscal year. (At the beginning of fiscal year 1977 only, this data will be extracted from other records if necessary.)

3. "PLAN", Area (2)

a. In the first column, list the sub-task numbers.

b. In the second column, list the corresponding work-order numbers.

c. In the "PRIOR CUM" column, enter the cumulative budgeted cost for work scheduled, for the tutal task and by sub-task, through the preceding September. These numbers can be found in the "ITD" column for September on the completed OWI Status Record for the preceding fiscal year. (At the beginning of fiscal year 1977 only, this data will be extracted from other records if necessary.)

4. "SCHEDULE VARIANCE", Area (3)

a. In the "PRIOR CUM" column, enter the accrued Schedule Variance value for the total task through the preceding September. This number can be found in the "ITD" column for September on the completed OWI Status Record for the preceding fiscal year. (At the beginning of fiscal year 1977 only, this data will be extracted from other records if necessary.) 
5. "ACTUALS", Area (4)

a. In the first column, list the sub-task numbers.

b. In the third column, list the corres ponding work-order numbers.

c. In the "PRIOR CUM" column, enter the cumulative actual costs of work performed on the total task and by sub-task, through the preceding September. This number can be found in the "ITD" column for September on the completed OWI Status Record for the preceding fiscal year. (At the beginning of fiscal year 1977 only, this data will be extracted from other records if necessary.)

6. "TASK COST VARIANCE", Area (5)

a. In the "PRIOR CUM" column, enter the accrued cost variance value for the total task through the preceding September. This number can be found in the "ITD" column for September on the completed OWI Status Record for the preceding fiscal year. (At the beginning of fiscal year 1977 only, this data will be extracted from other records if necessary.)

\section{7. "LISTING OF SUBTASKS AND DESCRIPTIONS"}

a. List by WBS number, all sub-tasks defined, in the WBS, for the task identified on the Status Record, with their corresponding descriptive titles.

\section{B. UPDATING THE RECORDS}

The following steps are to be followed to update the records.

1. "TASK DESCRIPTION" and "DATE"

a. Change the date to the date of updating.

2. "PROGRESS", Area (1)

a. In the "MO." column for the month, enter the budgeted cost for work performed during the month, by sub-task. 
b. For each sub-task, add together the monthly budgeted costs in the fiscal year, to date; and enter the cumulative total in the "YTD" column for the latest month. However, October YTD costs are invariably a repetition of the MO. costs for October.

c. Add the YTD values Just computed to the PRIOR.CUM. values, by subtask; and enter these sums in the ITD column for the month.

d. Finally, sum the data in each column and enter the respective totals in the TASK TOTAL line.

3. "PLAN", Area (2)

a. 'In the "MO." column for the month, enter the budgeted cost for work scheduled to be accomplished during the month, by sub-task.

b. For each sub-task, add together these monthly budgeted costs in the fiscal year, to date; and enter the cumulative total in the "YTD" column for the latest month. However, October YTD costs are invariably a repetition of the MO. costs for October.

c. Add the YTD values just computed to the PRIOR CUM. values, by subtask; and enter the sub-task sums in the ITD column for the month.

d. Finally, sum the new data in each column and enter the respective totals in the TASK TOTAL line.

4. "SCHEDULE VARIANCE", Area

(3)

a. Using the new Task Totals, subtract the Plan costs from the Progress costs, by column; and enter the differences in their respective columns. Denote any negative value by enclosing the number in - parentheses.

5. "ACTUALS", Aree (4)

a. In the "MO." column for the month, enter the actual cost of work accomplished during the month, by sub-task. 
b. For each sub-task, add together its monthly actual costs in the fiscal year to date; and enter the cumulative total in the "YTD" column for the latest month. October YTD costs invariably repeat the MO. costs for October.

c. Add the YTD values just computed to the PRIOR CUM. values, by sub-task; and enter these sub-task sums in the ITD column for the month.

d. Finally, sum the new data in each column and enter the respective totals on the TASK TOTAL line.

6. "TASK COST VARIANCE", Area (5)

a. Using new Task Totals, subtract the Actuals costs from the Progress costs, by column; and enter the differences in their respective columns. Denote any negative value by enclosing the number in parentheses.

7. COMPLETION (COMPL), Area (4)

a. When a task is completed, enter the date of completion in the second column, COMPL.

\section{4-4 STATUS REPORTING}

Numerous media forms will be utilized by OWI to provide the various levels of management with the information necessary to enhance the decision making process. These will include graphic presentations, narrative reports and program/ project reviews.

\section{A. GRAPHIC PRESENTATIONS}

Various graphic displays will be utilized by OWI including information from the OWI Status Record and WBS Form, Schedule Reports (milestone/Gantt charts), and networks. The following are two examples of graphic presentations derived from the OWI Status Record and Work Breakdown Structure Form. 
1. Output Report Number 1

Output Report Number 1, figure 4-3, shows the monthly, year-to-date (YTD), and inception-to-date (ITD) of the sub-tasks (except the lowest level tasks) being monitored. The graph shows the accumulated schedule, accumulated accomplished work, and accumulated expenditure from (hypothetically) October to April for Plant and Capital Equipment and Operating Cost expenditures. The schedule variance is determined by subtracting the "Work Scheduled" from the "Work Accomplished". The Cost Variance is determined by subtracting the "Dollar (\$) Spent" from the "Work Accomplished".

2. Output Report Number 2

Output Report Number 2, figure 4-4, shows the budgeted dollars for each task versus the actual budgeted dollars (or commitments) which have been derived from the UCC-ND cost accounting records. This graph shows the difference between the anticipated (planned) budget versus the actual budget allocation. The budget commitment dollars are derived from information recorded on the WBS Form (figure 4-1, Area (6)). Information for the presentation of actual commitment dollars is derived from UCC-ND cost account records sorted by work-order number.

\section{B. NARRATIVE REPORTS}

1. Cost, Schedule, Technical Status Reports Narrative repurls will be provided by contractors and the various levels of OWI management concerning cost, schedule and technical performance. As a rule these reports will describe the significant accomplishments during this reporting period and a forecast of the significant events to be completed during the next twelve weeks. An assessment of the current cost and schedule position will be included.

2. Problem Analysis Reports

Cost and schedule variance tolerances will be established by OWI management at the various reporting levels. When these acceptable tolerances 


\section{OUTPUT REPORT \#1}

\section{DESCRIPTION: 1161.2 SYSTEMS DEVELOPMENT}

KS COST (P \& CE AND OPERATING)

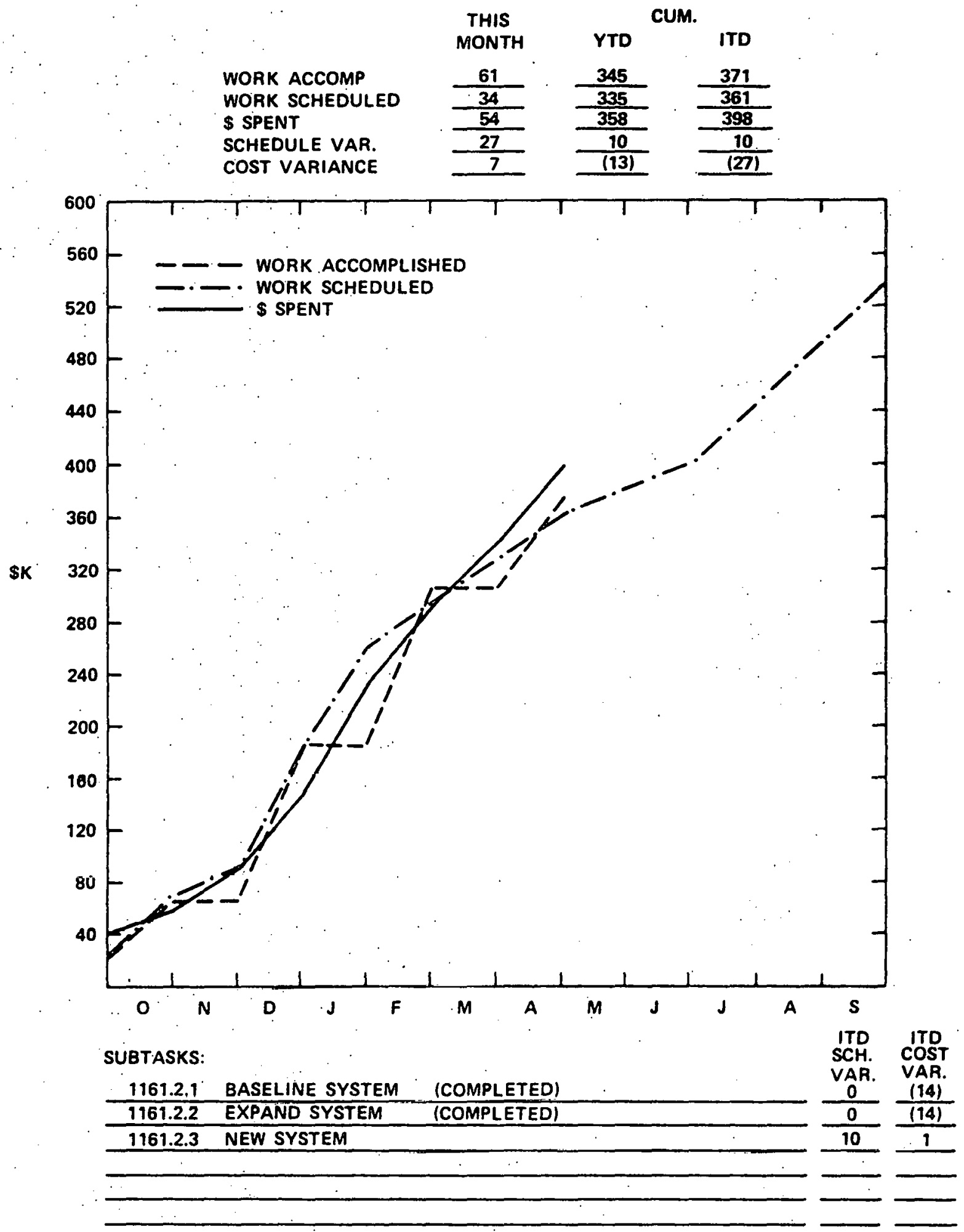

Figure 4-3. Output Report \#1 
OUTPUT REPORT $\# 2$

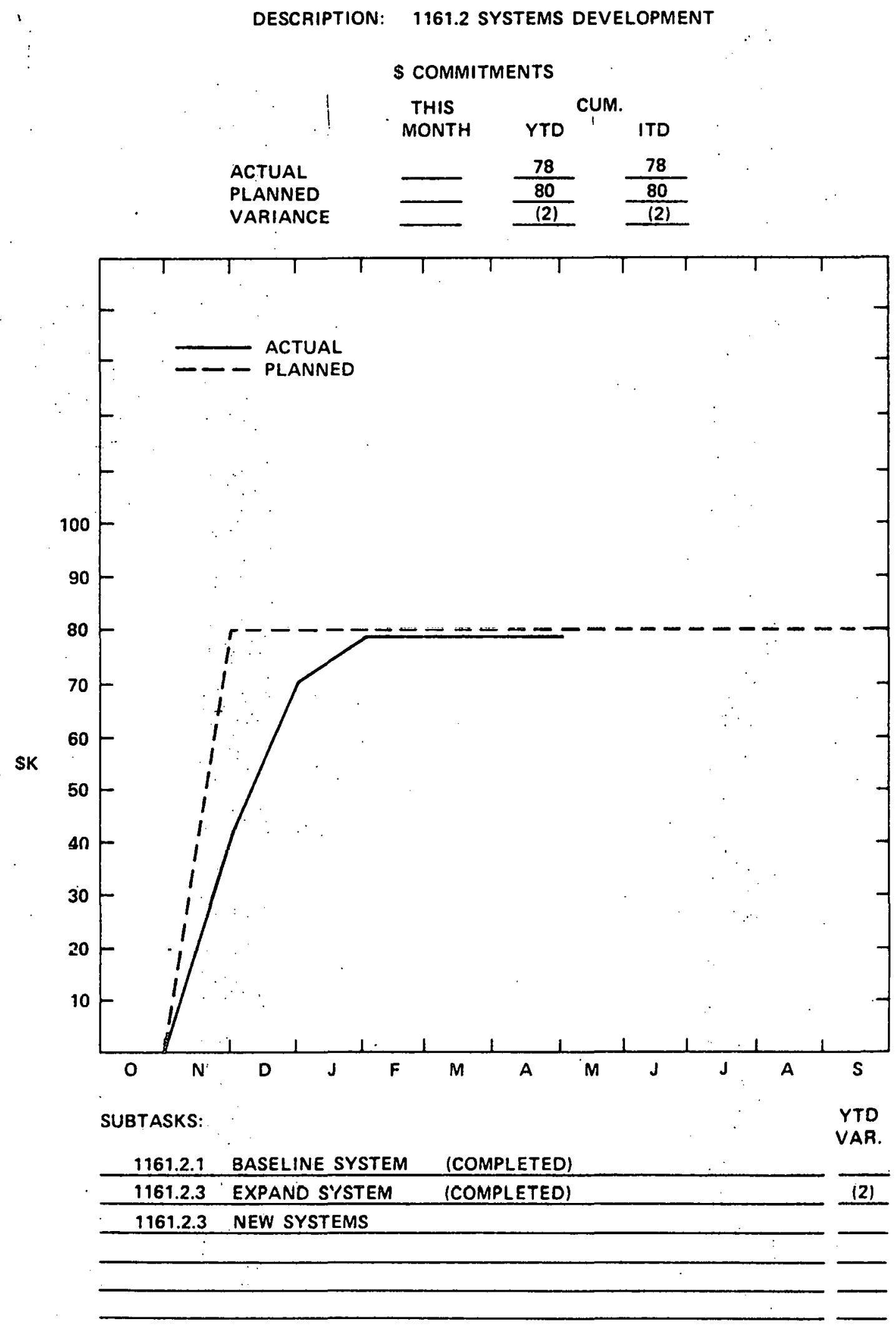

Figure 4-4. Output Report \#2 
are exceeded a Problem Analysis Report Form will be completed by the responsible organizational entity. OWI will develop the Problem Analysis

Form based upon the following criteria for the information to be included:

- Identification of the problem

- The affected WBS element or the contracted task title and number

- The schedule date for completion of the milestone

- The estimated completion date for the subject milestone

- An analysis of the problem and its cause

- ... Total impact assessment if the problem is not corrected

(The project management network should be referenced.)

- The corrective action to be implemented

- A revised completion date for the milestone based upon the corrective action

- Person responsible for implementation of the corrective action

- Person(s) reviewing and approving the Problem Analysis Report.

C. NWTS PROGRAM/PROJECT REVIEWS

1. Office of Waste Isolation

On a regular basis, OWI management will convene for a general review of the NWTS program. The main focus of the review will be the thorough analysis of the new information provided by the latest monthly reports developed in accordance with the procedures above. Unresolved problems and decision requirements identified in earlier reviews will also be analyzed in the light of the latest information.

2. External

a. UCC-ND Program Reviews

The Director of the OWI will conduct program reviews for reporting the accomplishments and prospects of the NWTS program to the management of the Union Carbide Corporation-Nuclear Division. 
b. Other Program Reviews

OWI will also plan and conduct program reviews for ERDA officials and other organizations as required.

\section{Contractor Reviews}

Certain contractors will be required to conduct status reviews for OWI management, and may, at the request of OWI, be asked to participate in the reviews defined above.

\section{REPORTING HIERARCHY}

Figure 4-5 portrays a simplified diagram of the reporting hierarchy and technique to be utilized by OWI. The objective of this technique is to simplify to the extent possible the management decision process by allowing each level of management to focus attention on defined exceptions. It is also evident from the diagram that the amount of detail is reduced by the summation process at each higher level of management. By utilizing this approach each level of the management structure is provided the optimal amount of information for his area of responsibility, with the capability to be provided with additional details as required.

To explain the concept in greater detail, figure 4-5 shows that the OWI Status Record is the basic document to be used by OWI managers and contractors in identifying problem areas. OWI managers will establish variance tolerances for use internally by OWI and by contractors. When Status Records are submitted by contractors to OWI and variance tolerances in their contracts are exceeded, the Status Reports will be accompanied by a completed Problem Analysis Form. The Problem Analysis Form will identify the problem for OWI managers, provide an analysis of the problem and a recommended solution when feasible. Similarly, when OWI Status Reports are aggregated within OWI and the varlances exceed the tolerances acceptable to a manager, the manager at the level at which the tolerance is exceeded will compiete a Problem Analysis Form. This Problem Analysis Form will be submitted to the next level of management within OWI. In the case of the Director, OWI, the information in the Problem Analysis Form may be utilized for external reporting. 
STATUS REPORTING/PROBLEM IDENTIFICATION CONCEPT
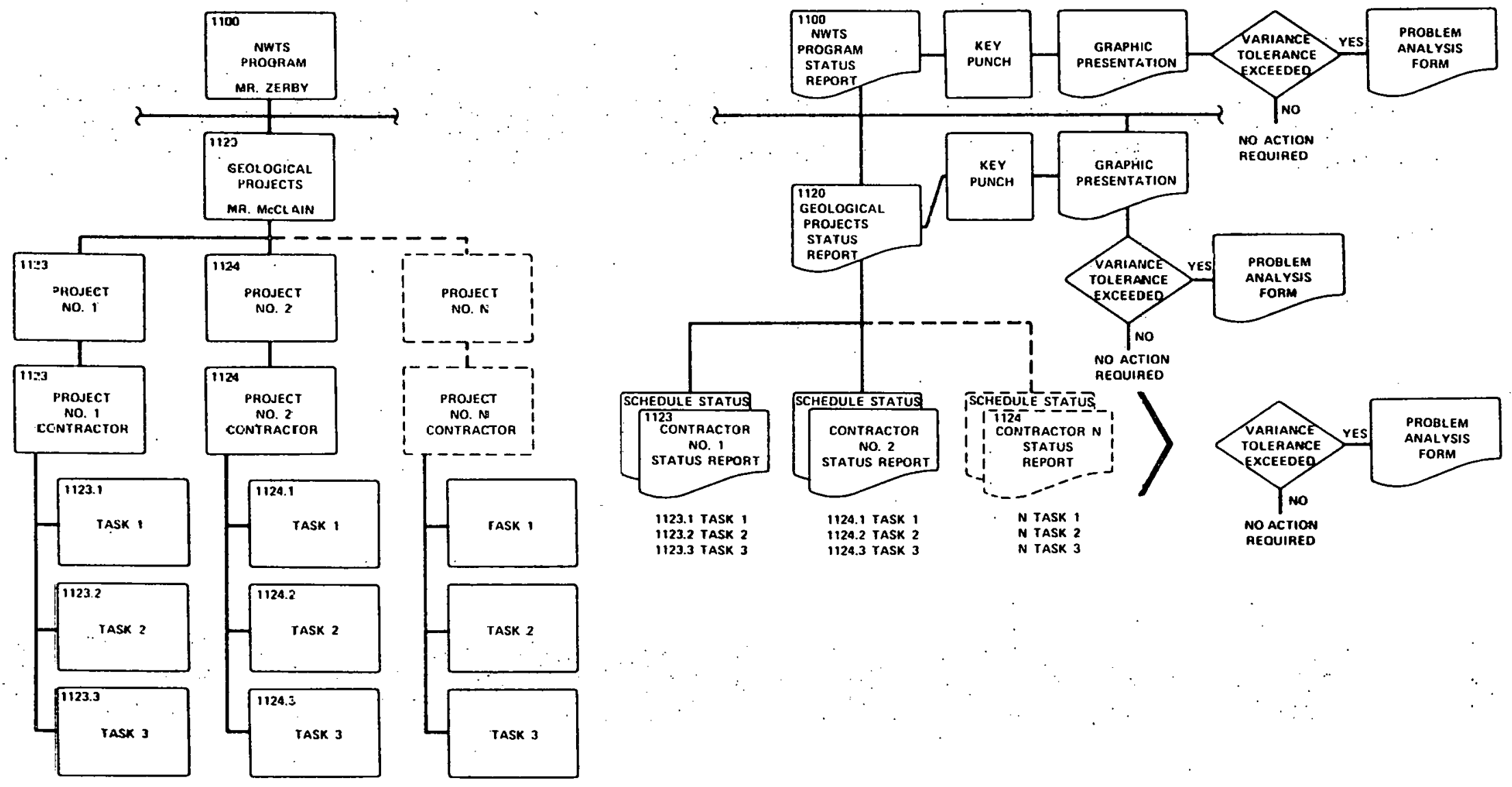

Figure 4-5. Status Feporting/Problem Identification Concept 


\section{$4-5$ CONTRACTOR CONTROL}

The following paragraphs define the mechanisms to be utilized by OWI for the management control of all contracted efforts. OWI will exercise one of two methods of control based upon the envisioned contract type, dollar value, and criticality to the NWTS program. The major difference between the two methods is the level of control required to provide cost/effective management visibility.

\section{A. CONTROL METHOD SELECTION}

Each proposed contracted effort will be reviewed by OWI management to establish the control method that is applicable.

The criteria for this selection process is:

- Contracts with a total value in excess of $\$ 500,000$

- Contracted efforts that are of a technical or schedule nature critical to the NWTS Program as assessed by OWI management

- As specifically directed by the OWI Program Director or his designated representative(s)

- Contracts other than fixed price or fixed price with escalation. All other contracts including fixed price incentive are candidates for detailed control.

\section{B. CONTROL METHOD NUMBER ONE METHODOLOGY}

For those contracted efforts that are selected for the utilization of control method number one the following methodology will be implemented by OWI.

1. Project Summary Work Breakdown Structure (PSWBS) OWI will be responsible for preparing the PSWBS to be included in the Request For Proposal (RFP) to identify the work to be accomplished by the successful bidder. The PSWBS will normally define 3 to 4 levels of detall in order not to be unduly restrictive as concerns the proposer's organiza tional structure and normal methods of work accomplishment. 
2. Contract Work Breakdown Structure (CWBS)

The RFP will instruct the competing contractors to extend the PSWBS as low as necessary to identify and structure the work effort to achleve the purpose of the eventual contract. This breakdown should be to manageable subtask entities approximating $\$ 50,000$ and 3 months duration. The prospective contractors will be allowed to suggest changes to the PSWBS to enhance the effectiveness of the CWBS in satisfying the contract objective. The CWBS as proposed by the prospective contractors will be a part of the OWI proposal evaluation process.

3. Project Work Breakdown Structure (PWBS)

The successful bidder's CWBS will be negotiated as required by OWI in consonance with the initial PSWBS. The purpose of this negotiation is to firmly establish the PWBS for the contract. Any subsequent changes to the negotiated PWBS will be formally controlled utilizing the change control mechanisms described in this section.

\section{CONTROL METHOD NUMBER TWO METHODOLOGY}

For those proposed contracted efforts which are not selected for in-depth OWI management visibility based upon the defined criteria, the following methodology will be utilized by OWI.

1. Project Work Breakdown Structure

The PWBS will be defined by OWI and utilized to develop the statement of work (SOW) in the RFP. The SOW may vary from a single element of work to a definition of the contract objective and a number of sub-tasks. The proposer's response to the SOW will be utillzed in the OWI evaluation process.

\section{CONTRACTOR REPORTING}

Regardless of the method of control selected by OWI for a particular contracted effort, the contractor reporting requirements are identical. Only the level of reporting is variable between the two methods. 


\section{OWI Status Record Form}

The contractor will provide to OWI monthly OWI Status Record Form(s), figure 4-2, depending upon the defined control level(s). The instructions for completing this form were previously defined in paragraph $4-3$ in this section.

\section{Schedule Status Report Form}

Schedules will be prepared for each work element to the level(s) agreed to by OWI and the contractor, and reported upon monthly, utilizing the Schedule Status Report Form, figure 4-6.

\section{Narrative Reports}

The OWI Status Record Form(s) and Schedule Status Report Form(s), submitted on a monthly basis by the contractor, will be accompanied by a narrative report describing the progress of the previous month and a forecast of the significant events to be completed during the next twelve weeks. An assessment of the current cost and schedule position will be included.

4. Problem Analysis Reports

Tolerances will be established by OWI, in conjunction with the contractor, for acceptable variances from planned schedules and budgets. Both the OWI Status Record Form and the Schedule Status Report Form provide for monthly variance quantification. In those instances where the variance tolerance is exceeded, the contractor will provide OW.I with a Problem Analysis Report Form as previously described in paragraph $4-4 B 2$ in this section.

\section{4-6 CHANGE CONTROL}

OWI will develop and implement a change control procedure for utilization by OWI and contractors. The following design criteria has been established for the eventual procedure:

- Provide complete definition of proposed changes. 
SCHEDULE STATUS REPORT

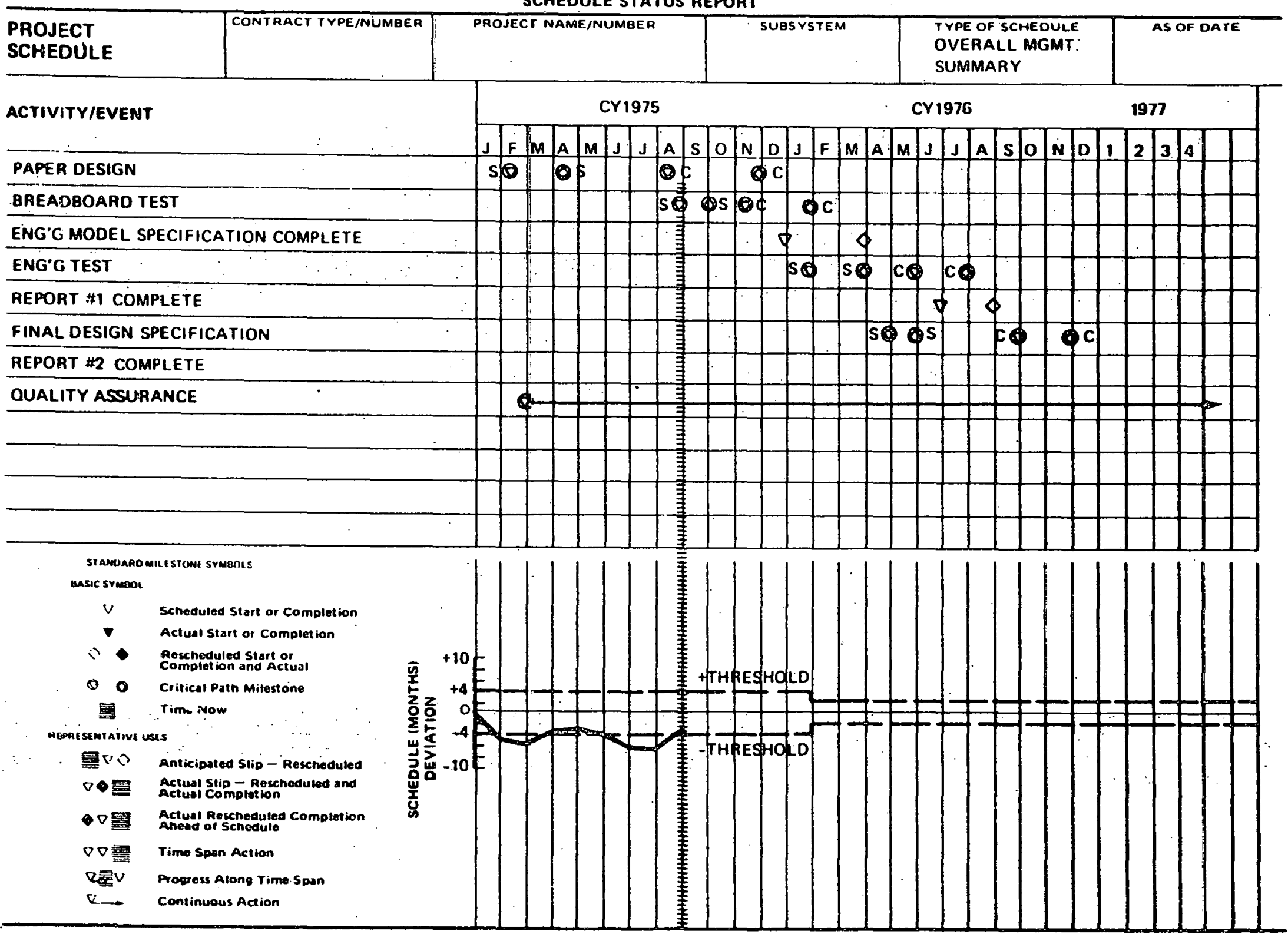

Figure 4-6. Schedule Status Report 
- Allow for the categorization and prioritizing of each proposed change.

- Assure total cost and schedule impact assessment prior to approval request.

- Method for approval.

- Scheduling and tracking of each change proposal.

- Implementation control.

- Traceability after implementation from the prior baseline to the revised baseline identification.

It is planned that this initial technical, budget, and schedule baseline change control procedure will be an integral part of the eventual NWTS Program Configuration Management System : 
U. S. Energy Research and Development Administration

J. J. Schreiber (2)

Office of Waste Isolation

J. M. Asher

K. K. Aydelotte

R. Blumberg

A. L. Boch

G. D. Brunton

E. B. Cobb

P. D. Fairchild

W. A. Goldsmith

R. B. Laughon

T. F. Lomenick

R. S. Lowrie

S. C. Matthews

L. L. McCauley

W. C. McClain

J. R. Palmer

A. S. Quist

R. L. Shoup

C. D. Zerby

OWI Records - RC
Operations Analys is and Planning

J. T. Bradbury

J. M. Morrison

J. E. Vath 